\title{
Soil salinity effects on phenological traits, plant height and seed yield in rapeseed genotypes
}

\begin{abstract}
Among the various abiotic stresses limiting the crop production, salinity stress is the most important problem, which needs to be addressed and answered straight away. A pot experiment was carried out with rapeseed breeding lines in order to study the effects of salinity stress on phenological traits, plant height and seed yield of rapeseed. A factorial experiment was applied for evaluating the eight rapeseed genotypes under three salinity levels including 0,6 and $12 \mathrm{dS} \mathrm{m}^{-1}$ taking $\mathrm{NaCl}_{\mathrm{CaCl}}$ in the ratio of $1: 1$, which were equal to $42.8 \mathrm{mM}$ and $85.7 \mathrm{mM}$, respectively. The results of analysis of the variance revealed significant variations among different salinity levels, genotypes and interaction effects of salinity levels $\times$ genotypes for days to flowering, days to end of flowering, days to maturity, plant height and seed yield. Due to increasing salinity levels, days to flowering, days to end of flowering and days to maturity were shortened. Although with increasing salinity levels plant height and seed yield of the genotypes were decreased but the ranks of genotypes were different in 0,6 and $12 \mathrm{dS} \mathrm{m}^{-1}$ salinity levels. The genotypes had significant genetic differences for the traits and the increments of differences also were decreased due to increasing salinity levels. The genotypes had high amount of genetic coefficient variation for days to flowering and seed yield, therefore the efficiency of selection of these two traits will be high. The genotypes including KRN1, LRT1 and Hyola401 with high amounts of seed yield in all salinity levels were considered as tolerant genotypes.
\end{abstract}

Key words: breeding lines, factorial experiment, rapeseed, salinity, seed yield.

\section{INTRODUCTION}

High salinity is a common abiotic stress factor that seriously affects crop production in some parts of the world, particularly in arid and semi-arid regions (Neumann 1995). There is verification that irrigation systems and type of irrigation water have contributed to a large extent in converting arable lands to saline lands (Ashraf and McNeilly 2004; Ajmal Khan and Weber 2006). High concentrations of salts cause ion imbalance and hyperosmotic stress in plants. As a result of these primary effects, a secondary stress such as oxidative damage often occurs. Saline environments affect the plant growth in different ways such as a reduce in water uptake, an accretion of ions to toxic levels, and a reduction of nutrient availability. The most common adverse effect of salinity on the crop of brassica is reduction of plant height, size and yield, as well as deterioration of the product quality (Munns and Termaat 1986; Bandeh-Hagh et al. 2008; Zamani et al. 2010). The salinity may reduce the crop yield by upsetting water and nutritional balance of plant (Francois 1996; Islam et al. 2001). Salt tolerance is also a very complex trait in plant species since it is governed by several mechanisms at cellular, tissue, organ, or whole plant levels. Some traits may only be efficient in a particular species for salinity tolerance. Additionally, the effect of one mechanism may prohibit the effect of the others at certain stages of plant development (Greenway and Munns 1980; Minhas et al. 1990; Gorham et al. 1993; Mahmoodzadeh 2008; Purty et al. 2008). The cultivated Brassica species include both diploid and polyploid species. Most of the Brassica species have been categorized as moderately salt tolerant, with the amphidiploids species being the relatively salt tolerant in comparison with the diploid species. Due to the higher salt tolerance of the amphidiploids, it has been suggested that their salt tolerance has been acquired from the A (Brassica campestris L.) and C (Brassica oleracea L.) genomes (Ashraf and McNeilly 2004). Some of quantitative traits such as phenological traits, yield components can be used for indirect selection of salinity tolerant genotypes in brassica genus. The most promising crop type likewise brassica oilseed crops for high seed yield combined late maturity with early flowering. Bybordi (2010) reported that with increasing salinity levels, days to flowering was increased but days to maturity 
was decreased in rapeseed cultivars. Abbaszadeh et al. (2012) stressed that due to increasing salinity level seed yield of rapeseed cultivars were decreased.

The aims of this study were to evaluate the effects of salt stress on phenological traits, plant height and seed yield and selection the superior genotypes of rapeseed in saline conditions.

\section{MATERIALS AND METHODS}

Eight diverse rapeseed genotypes including six breeding lines (KRN3, NDK6, KRN1, KRN2, DSM12 and LRT1) and two cultivars (Zarfam and Hyola401) were evaluated in three salinity levels of irrigation water including 0,6 and $12 \mathrm{dS} \mathrm{m}^{-1}$ taking $\mathrm{NaCl}: \mathrm{CaCl}_{2}$ in the ratio of $1: 1$ which were equal to $42.8 \mathrm{mM}$ and $85.7 \mathrm{mM}$, respectively at Agriculture and Natural Resources Research Center of Mazandran, Sari, Iran, during 2010-2011 cropping season. A factorial experiment based on completely randomized design (CRD) with 4 replications was considered for evaluation of 24 treatments. The salt solution was prepared by taking $\mathrm{NaCl}: \mathrm{CaCl}_{2}$ in the ratio of $1: 1$ and the electrical conductivity of different salinity levels was adjusted by a direct reading conductivity meter. Soil analysis results are shown in Table 1. The soil belongs to the non-saline soil with a neutral reaction and the amount of lime which is relatively high $(\mathrm{CCE}=13 \%)$. Levels of nutrients, soil organic matter levels in the medium and other nutrients, including potassium, phosphorus, iron, manganese and copper are desirable. In each plot 10 seeds were planted in separate 10-liter pots and five plants were maintained for evaluating. Electrical conductivities of the saline treatments were increased to the desired levels by incremental additions of the salts over 10-day period to avoid osmotic shock to the seedlings. Plants in all pots were irrigated until saturation, with the excess solution allowed to drain into collection pans. All pots were maintained at farm condition and also they were isolated from raining. The studied traits were days to flowering, days to end of flowering, days to maturity, plant height and seed yield. All the traits were analyzed based on factorial experiments based on completely randomized and means comparison was done based on least significant difference test (Gomez and Gomez 1984).

\section{RESULTS AND DISCUSSION}

The analysis of the variance based on factorial experiment showed significant variations among the treatments (different salinity levels), genotypes and their interaction (salinity-genotypes) for days to flowering, days to end of flowering, days to maturity, plant height and seed yield (Table 2). These results indicate that the levels of salinity had different influence, and the genotypes had distinctive responses to salinity levels for the traits. Similarly, in earlier study (Abbaszadeh et al. 2012) significant effect of salinity levels, genotypes and the interactions between yield and yield components in rapeseed was reported. Due to significant genotype effect for the traits which is indicating significant genetic variation for these traits, selection of tolerant genotypes based on phenological traits and plant height as selection criteria will be efficient for improving the seed.

The result of means comparison related to salinity levels is presented in Table 3. Due to increasing of salinity levels, the phenological traits including days to flowering, days to end of flowering and days to maturity were decreased. Root zone salinization affects plant ontogeny. For example, Maas and Grieve (1990) and Grieve et al. (1994) reported that salt stress

TABLE 1. Some of physicochemical properties of soil samples

\begin{tabular}{|c|c|c|c|c|c|c|c|c|c|c|c|c|c|}
\hline \multirow[t]{2}{*}{ Class } & \multicolumn{3}{|c|}{ Soil texture $(\%)$} & \multicolumn{6}{|c|}{ Content of elements $\left(\mathrm{mg} \mathrm{kg}^{-1}\right)$} & \multirow{2}{*}{$\begin{array}{l}\mathrm{CCE} \\
-(\%)\end{array}$} & \multirow{2}{*}{$\begin{array}{l}\mathrm{OC} \\
(\%)\end{array}$} & \multirow[t]{2}{*}{$\mathrm{pH}$} & \multirow{2}{*}{$\begin{array}{l}\mathrm{EC} \\
\left(\mathrm{dS} \mathrm{\textrm {m } ^ { - 1 }}\right)\end{array}$} \\
\hline & Clay & Silt & Sand & $\mathrm{Cu}$ & $\mathrm{Zn}$ & $\mathrm{Mn}$ & $\mathrm{Fe}$ & $\mathrm{K}$ & $\mathrm{P}$ & & & & \\
\hline Si-C-L & 26 & 56 & 18 & 2.5 & 0.65 & 3.2 & 8 & 321 & 7.8 & 13 & 1.34 & 7.2 & 0.65 \\
\hline
\end{tabular}

CCE: calcium carbonate equivalent, OC: organic carbon, EC: electrical conductivity.

TABLE 2. Summary of analysis of variance for phenological traits, plant height and seed yield

\begin{tabular}{lcccccc}
\hline S.O.V & df & M.S & & & \\
\cline { 3 - 6 } & & $\begin{array}{l}\text { days } \\
\text { to flowering }\end{array}$ & $\begin{array}{l}\text { days to end } \\
\text { of flowering }\end{array}$ & $\begin{array}{l}\text { days to } \\
\text { maturity }\end{array}$ & plant height & seed yield \\
\hline Salinity (S) & 2 & $634.81^{* *}$ & $785.17^{* *}$ & $831.13^{* *}$ & $4929.02^{* *}$ & $21.58^{* *}$ \\
Genotypes(G) & 7 & $1934.35^{* *}$ & $574.63^{* *}$ & $181.19^{* *}$ & $765.79^{* *}$ & $7.38^{* *}$ \\
$\mathrm{~S} \times \mathrm{G}$ & 14 & $14.17^{* *}$ & $11.87^{* *}$ & $15.40^{* *}$ & $242.01^{* *}$ & $0.43^{* *}$ \\
Error & 72 & 2.62 & 1.80 & 3.42 & 56.30 & 0.11 \\
\hline
\end{tabular}

S.O.V. - Source of variance, df: degree of freedom, M.S: Mean squares. ** Significant at the $1 \%$ levels of probability. 
TABLE 3. Mean comparison of phenological traits, plant height and seed yield for salinity levels based on least significant differences (LSD) test

\begin{tabular}{llllll}
\hline $\begin{array}{l}\text { Salinity } \\
\text { levels } \\
\left(\mathrm{dsm}^{-1}\right)\end{array}$ & $\begin{array}{l}\text { Days to } \\
\text { flowering }\end{array}$ & $\begin{array}{l}\text { Days to end } \\
\text { of flowering }\end{array}$ & $\begin{array}{l}\text { Days } \\
\text { to maturity }\end{array}$ & $\begin{array}{l}\text { Plant } \\
\text { height } \\
(\mathrm{cm})\end{array}$ & $\begin{array}{l}\text { Seed } \\
\text { yield } \\
(\mathrm{g} / \mathrm{plot})\end{array}$ \\
\hline $\mathrm{S} 1=0$ & $84.37 \mathrm{a}$ & $123.82 \mathrm{a}$ & $171.50 \mathrm{a}$ & $70.99 \mathrm{a}$ & $2.84 \mathrm{a}$ \\
$\mathrm{S} 2=6$ & $80.06 \mathrm{~b}$ & $115.20 \mathrm{~b}$ & $166.13 \mathrm{~b}$ & $53.12 \mathrm{~b}$ & $1.62 \mathrm{~b}$ \\
$\mathrm{~S} 3=12$ & $75.46 \mathrm{c}$ & $113.95 \mathrm{~b}$ & $163.31 \mathrm{~b}$ & $47.13 \mathrm{c}$ & 1.28 \\
\hline
\end{tabular}

Means, in each column, followed by at least one letter in common are not significantly different at the $1 \%$ level of probability.

accelerated development of the wheat shoot apex on the main stem by as much as 18 days and decreased the time to initiation of reproductive structures. They also noted a shorter time to flowering. Accelerated phenological development may not essentially be a common response among all plant species, as confirmed by Rawson (1986), who reported no change in phenology of barley in response to $\mathrm{NaCl}$ up to 150 mol m$~^{-3}$. Days to flowering was varied from 75.46 and 84.37 days related to 0 and $12 \mathrm{dS} \mathrm{m}^{-1}$, respectively. Although due to increasing salinity days to end of flowering was decreased but amount of this trait related to 6 and $12 \mathrm{dS} \mathrm{m}^{-1}$ were classified as the same statistical group. Days to maturity was varied from 171.5 to 161.31 days for 0 and $12 \mathrm{dS} \mathrm{m}^{-1}$, respectively. Due to increasing of salinity the phenological traits and subsequently plant height were decreased.

Saline solutions also affect cell growth directly although the precise mechanism by which this occurs remains unclear (Ashraf and McNeilly 2004). According to the biophysical model of cell elongation, the rate of cell elongation is regulated or controlled by alterations in any of several parameters: cell wall extensibility, turgor pressure, and yield threshold. Yield threshold refers to the value of turgor pressure below which no irreversible cell wall extension occurs. Because increased salt concentration lowers the osmotic potential of the soil solution, a prevailing notion is that root zone salinity affects growth by lowering cell turgor. Sudden decreases in turgor pressure changes are undoubtedly responsible for the inhibition of growth induced by rapid increase in external solute concentrations (Volkamar et al. 1998). Due to plant height decreasing, most yield components were decreased and therefore seed yield was reduced.

Days to flowering varied from 61.08 to 95.58 related to LRT1 and NDK6, respectively (Table 4). The high mean values of days to flowering were detected for NDK6, Zarfam and DSM12 with 96.58, 95.75 , and 89.50 days to flowering, respectively. The high number of days to end of flowering were determined for NDK6, Zarfam and KRN1. Days to maturity varied from 160.50 to 169 in DSM12 and
Zarfam, respectively. Plant height ranged from 43.47 to $66.64 \mathrm{~cm}$ in KRN2 and LRT1, respectively. Days to flowering and days to maturity had the highest and lowest amount of genetic coefficient of variation, the refore among these genotypes selection efficiency for days to flowering will be high. The high amounts of seed yield were related to Hyola401, LRT1 and KRN1, therefore these genotypes will be good candidate for seed yield improving.

TABLE 4. Mean comparison of phenological traits, plant height and seed yield for eight rapeseed (Brassica napus L.) genotypes based on least significant differences (LSD) test

\begin{tabular}{lcllll}
\hline Variety & $\begin{array}{l}\text { Days to } \\
\text { flowering }\end{array}$ & $\begin{array}{l}\text { Days } \\
\text { to end } \\
\text { of flowering }\end{array}$ & $\begin{array}{l}\text { Days } \\
\text { to } \\
\text { maturity }\end{array}$ & $\begin{array}{l}\text { Plant } \\
\text { heigh } \\
\text { t }(\mathrm{cm})\end{array}$ & $\begin{array}{l}\text { Seed } \\
\text { yield } \\
\text { (g/plot) }\end{array}$ \\
\hline 1-KRN3 & $73.83 \mathrm{~d}$ & $117.58 \mathrm{c}$ & $161.50 \mathrm{~d}$ & $56.18 \mathrm{bc}$ & $1.50 \mathrm{~d}$ \\
2-NDK6 & $96.58 \mathrm{a}$ & $128.33 \mathrm{a}$ & $166.67 \mathrm{~cd}$ & $53.58 \mathrm{bc}$ & $1.64 \mathrm{~cd}$ \\
3-Zarfam & $95.75 \mathrm{a}$ & $126.00 \mathrm{a}$ & $169.00 \mathrm{~b}$ & $50.12 \mathrm{~cd}$ & $1.42 \mathrm{~d}$ \\
4-KRN1 & $77.36 \mathrm{c}$ & $123.42 \mathrm{~b}$ & $172.25 \mathrm{a}$ & $60.95 \mathrm{ab}$ & $2.30 \mathrm{~b}$ \\
5-KRN2 & $74.83 \mathrm{~d}$ & $117.33 \mathrm{c}$ & $168.25 \mathrm{bc}$ & $43.47 \mathrm{~d}$ & $0.68 \mathrm{e}$ \\
6-DSM12 & $89.50 \mathrm{~b}$ & $117.00 \mathrm{c}$ & $160.50 \mathrm{e}$ & $66.53 \mathrm{a}$ & $1.89 \mathrm{c}$ \\
7-LRT1 & $61.08 \mathrm{f}$ & $110.83 \mathrm{~d}$ & $167.25 \mathrm{bc}$ & $66.64 \mathrm{a}$ & $2.78 \mathrm{a}$ \\
8-Hyola401 & $70.75 \mathrm{e}$ & $108.75 \mathrm{~d}$ & $165.08 \mathrm{~d}$ & $59.15 \mathrm{ab}$ & $3.09 \mathrm{a}$ \\
\hline GCV & 15.88 & 5.83 & 2.34 & 14.00 & 40.96 \\
\hline
\end{tabular}

Based on LSD test, means, in each column, followed by at least one letter in common are not significantly different at the $1 \%$ level of probability. GCV: Genetic coefficient of variation.

The result of interaction effect of salinity levels and genotypes for the traits was shown in Table 5. Most of the genotypes with high number of days to flowering at control condition $\left(0 \mathrm{dS} \mathrm{m}^{-1}\right)$ had also high amounts of this trait in 6 and $12 \mathrm{dsm}^{-1}$ which indicating the prime importance of genetic effects for days to flowering. Days to end of flowering varied from 64.50 to $101.67,61.50$ to 97.33 , and 57.25 to 92.67 days related to 0,6 and $12 \mathrm{dS} \mathrm{m}^{-1}$, respectively. Although the genotypes had significant differences for this trait (i.e. days to end of flowering), but the increments of differences were decreased due to increasing salinity levels. The high number of days to end of flowering were related to NDK6, Zarfam and $\mathrm{KRN} 1$ at $0 \mathrm{dS} \mathrm{m}^{-1}$ and the low amounts of this trait were detected in LRT1 and Hyola401 at $12 \mathrm{dS} \mathrm{m}^{-1}$. KRN1, NDK6 and Hyola401 with 176.25, 174 and 174 days to maturity, respectively, had high amounts of this trait at $0 \mathrm{dS} \mathrm{m}^{-1}$. Plant height varied from 53.39 to $80.65 \mathrm{~cm}, 34.77$ to $66.06 \mathrm{~cm}$, and 34.49 to 64.24 $\mathrm{cm}$ at 0,6 and $12 \mathrm{dS} \mathrm{m}^{-1}$, respectively. The genotypes including KRN1, LRT1 and Hyola401 had high amounts of seed yield in all salinity levels and therefore these genotypes were considered as tolerant genotypes. Bybordi (2010) reported that with increasing salinity levels, days to flowering was increased but days to maturity was decreased in rapeseed cultivars. In this 
TABLE 5. Interaction effect of salinity levels (S) and genotypes $(\mathrm{G})$ means for phenological traits, plant height and seed yield

\begin{tabular}{lrllll}
\hline Treatments & $\begin{array}{l}\text { Days to } \\
\text { flowering }\end{array}$ & $\begin{array}{l}\text { Days to } \\
\text { end of } \\
\text { llowering }\end{array}$ & $\begin{array}{l}\text { Days } \\
\text { to } \\
\text { maturity }\end{array}$ & $\begin{array}{l}\text { Plant } \\
\text { height } \\
\text { (cm) }\end{array}$ & $\begin{array}{l}\text { Seed } \\
\text { yield } \\
\text { (g/plot) }\end{array}$ \\
\hline 1-S1G1 & 76.25 & 123.58 & 167.25 & 80.65 & 2.45 \\
2-S1G2 & 101.67 & 133.50 & 171.00 & 65.75 & 2.57 \\
3-S1G3 & 99.08 & 132.33 & 174.00 & 53.59 & 2.43 \\
4-S1G4 & 82.17 & 128.25 & 176.25 & 66.70 & 3.25 \\
5-S1G5 & 81.67 & 121.25 & 171.25 & 65.68 & 1.33 \\
6-S1G6 & 94.83 & 121.92 & 166.00 & 77.42 & 2.58 \\
7-S1G7 & 64.50 & 116.50 & 172.25 & 79.63 & 4.01 \\
8-S1G8 & 74.75 & 113.25 & 174.00 & 78.51 & 4.14 \\
9-S2G1 & 72.75 & 115.83 & 162.00 & 53.41 & 1.08 \\
10-S2G2 & 95.42 & 129.00 & 166.50 & 49.64 & 1.40 \\
11-S2G3 & 97.33 & 126.58 & 167.50 & 48.88 & 1.06 \\
12-S2G4 & 79.50 & 124.25 & 173.25 & 66.06 & 2.24 \\
13-S2G5 & 73.17 & 119.00 & 169.25 & 34.77 & 0.47 \\
14-S2G6 & 90.58 & 113.92 & 158.25 & 63.43 & 1.33 \\
15-S2G7 & 61.50 & 109.50 & 167.25 & 56.06 & 2.87 \\
16-S2G8 & 70.25 & 107.50 & 165.00 & 52.70 & 2.49 \\
17-S3G1 & 72.50 & 113.33 & 155.25 & 34.49 & 0.99 \\
18-S3G2 & 92.67 & 122.50 & 162.50 & 45.36 & 0.96 \\
19-S3G3 & 90.83 & 119.08 & 165.50 & 47.89 & 0.76 \\
20-S3G4 & 70.42 & 117.75 & 167.25 & 50.11 & 1.42 \\
21-S3G5 & 69.67 & 111.75 & 164.25 & 29.98 & 0.26 \\
22-S3G6 & 83.08 & 115.17 & 157.25 & 58.76 & 1.76 \\
23-S3G7 & 57.25 & 106.50 & 162.25 & 64.24 & 1.48 \\
24-S3G8 & 67.25 & 105.50 & 156.25 & 46.26 & 2.66 \\
\hline LSD( $\alpha=0.05)$ & 3.16 & 2.62 & 3.61 & 14.64 & 0.65 \\
\hline LSD( $\alpha=0.01)$ & 3.81 & 3.16 & 4.35 & 17.67 & 0.78 \\
\hline
\end{tabular}

$\mathrm{S} 1=0 \mathrm{dS} \mathrm{m}^{-1}, \mathrm{~S} 2=6 \mathrm{dS} \mathrm{m}^{-1}, \mathrm{~S} 3=12 \mathrm{dS} \mathrm{m}^{-1}, \mathrm{G} 1: \mathrm{KRN} 3, \mathrm{G} 2: \mathrm{NDK} 6, \mathrm{G} 3$ : Zarfam, G4: KRN1, G5: KRN2, G6: DSM12, G7: LRT1, G8: Hyola401.

study also due to increasing salinity level, plant height, most of yield components and seed yield were decreased.

\section{CONCLUSIONS}

In general due to increasing salinity levels, phenological traits including days to flowering, days to end of flowering, and days to maturity were decreased. The genotypes had high amount of genetic coefficient variation for days to flowering and seed yield, therefore the efficiency of selection these two traits will be high. Although with increasing salinity levels plant height and seed yield of the genotypes were decreased, but the ranks of genotypes were different in 0,6 and 12 $\mathrm{dS} \mathrm{m}{ }^{-1}$ salinity levels.

\section{REFERENCES}

Abbaszadeh F., Rameeh V., Charati A., 2012. Salinity Stress Indices of Seed Yield and Nutrient Compositions in Rapeseed. International Journal of Biology, 4(1): 154-162.

Ajmal Khan M., Weber D.J., 2006. Ecophysiology of high salinity Tolerant plants. Springer, The Netherlands, pp. 11-30.
Ashraf M., McNeilly T., 2004. Salinity tolerance in brassica oilseeds. Critical Reviews in Plant Sciences, 23(2): 157-174.

Bandeh-Hagh A., Toorchi M., Mohammadi M., 2008. Growth and osmotic adjustment of canola genotypes in response to salinity. Journal of Food, Agriculture and Environment, 6(2): 201-208.

Bybordi A., 2010. Effects of salinity on yield and component characters in canola (Brassica napus L.) cultivars. Notulae Scientia Biologicae, 2(1): 81-83.

Francois L. E., 1996. Salinity effects on four sunflower hybrids. Agronomy Journal, 88: 215-219.

Gomez K.A., Gomez A.A., 1984. Statistical procedures for agricultural research; John Wiley and Sons, New York.

Gorham J., 1993. Genetics and physiology of enhanced K/Na discrimination. In Genetic aspects of plant mineral nutrition. Randall P., Ed.; Kluwer Academic Publishers, Dordrecht, The Netherlands. pp: 151-159.

Greenway H., Munns R., 1980. Mechanisms of salt tolerance in no halophytes. Annual Review of Plant Physiology, 31: 149190.

Grieve C.M., Francois L.E., Maas E.V., 1994. Salinity affects the timing of phasic development in spring wheat. Crop Science, 34: 1544-1549.

Islam M.R., Bhuiyan M.A.R., Prasad B., Quddus M.A., 2001. Salinity effect on yield and component characters in rapeseed and mustard varieties. Journal of Biological Sciences, 1(9): 840-842.

Mahmoodzadeh H., 2008. Comparative study of tolerant and sensitive cultivars of Brassica napus in response to salt conditions. Asian Journal of Plant Sciences, 7(6): 594-598.

Maas E.V., Grieve C.M., 1990. Spike and leaf development in salt-stressed wheat. Crop Science, 30: 1309-1313.

Minhas P.S., Sharam D.R., Khosla B.K., 1990. Effect of alleviation of salinity stress at different growth stages of Indian mustard (Brassica juncea). Indian Journal of Agricultural Sciences, 60(5): 343-346.

Munns R., Termaat A.,1986. Whole-plant responses to salinity. Australian Journal of Plant Physiology, 13: 143-160.

Neumann P.M., 1995. Inhibition of root growth by salinity stress: Toxicity or an adaptive biophysical response, pp: 299-304. [In:] Baluska, F., Ciamporova, M., Gasparikova, O., Barlow, P.W. (Eds.). Structure and Function of Roots. The Netherlands: Kluwer Academic Publishers.

Purty R.S., Kumar G., Singla-Pareek L.S., Pareek A., 2008. Towards salinity tolerance in Brassica: an overview. Physiology and Molecular Biology of Plants, 14(1): 39-49.

Rawson H.M., 1986. Gas exchange and growth in wheat and barley grown in salt. Australian Journal of Plant Physiology, 13: 475-489.

Volkamar K.M., Hu Y., Steppuhn H., 1998. Physiological responses of plants to salinity: A review. Canadian Journal of Plant Science, 78: 19-27.

Zamani Z., Nezami M.T., Habibi D., Khorshidi M.B., 2010. Effect of quantitative and qualitative performance of four canola cultivars (Brassica napus L.) to salinity conditions. Advances in Environmental Biology, 4(3): 422-427.

Received: March 26, 2015

Accepted: June 16, 2015 